\section{Tietolastuja tieteestä ja tiedeviestinnästä}

Mari Heikkilä \& Tuukka Tammi (toim.) (2020). Viheliäs tiede - ja muita vaikeita uutisia. Vastapaino. 243 sivua.

”TOIMITTAJAN KANNALTA on todella viheliäistä, etteivät tutkijat usein anna suoriin kysymyksiin suoria vastauksia”, kirjoittaa Annikka Suoninen omassa Viheliä̈n tieteen artikkelissaan (s. 138). Tutkijoiden varovaisuudelle on kuitenkin syynsä, ja niistä pääsee hiukan jyvälle tämän tiedetoimittajajoukon laatiman teoksen välityksellä. Kirjan neljä alalukua sisältävät uskomuksia, kiihkeyttä, vauhtia ja värinymmärryksiä.

\section{USKOMUKSIA}

Ensimmäiset tekstit käsittelevät dogmeja, monitieteisyyden vaikeuksia, vihapuhetta ja vääristelyä. Nämä sosiaaliset faktat ovat monin verroin hankalampia käsiteltäviä kuin minkään muun lajin faktat, ja ehkä tämän takia teoksen ensimmäinen osio onkin noin puolen kirjan mittainen.

Avausteksti on toimittajilta dramaturginen täsmävalinta. Kliinisestä lääketieteestä poimimansa esimerkin avulla Erkki Karvonen piirtää tulikirjaimin lukijan tajuntaan, että uskomukset vaikuttavat voimallisesti myös tieteellisen tutkimuksen maailmassa, minkä seuraukset voivat olla hyvinkin ikäviä ja pitkäkestoisia. Tieteen kriitikkona on hänen mukaansa helppo esiintyä osittain sen takia, että tieteellinen tieto ei anna yhtä ainoaa oikeaa vastausta yhteenkään tutkittuun kysymykseen. Uskomuksen ja tieteellisen tutkimuksen tuottaman tiedon ero olisi siis siinä, että uskomus tarjoaa varman vastauksen, tieteellinen tutkimus puolestaan vastaa korkeintaan varauksin?

Kysymykset uskomuksista, hyödyllisen kriittisyyden ja haitallisen denialismin rajasta ovat läsnä myös tieteellisen tutkimuksen maailmoissa. Ne piirtyvät joskus kipeästi esiin varsinkin monitieteisissä tutkimushankkeissa, kirjoittaa Sanna Kivimäki. Pahimmillaan kilpalaulanta siitä, minkä tieteen- tai oppialan käsitteet ja metodit ovat parhaita, haittaa tutkimustyötä. Monitieteisissä hankkeissa on tärkeää ja välttämätöntä keskustella, jotta yhteinen perusta löytyisi. Keskustelu ei kuitenkaan saa muuttua tutkimusta haittaavaksi reviiritaisteluksi.

Toimittajilla - tiedetoimittajat mukaan lukien - on tapana rakentaa jutulleen valmis sapluuna, johon tutkijoilta haetaan sopivia sisältöjä. Myös tutkijat askartelevat vastaavalla tavalla: tutkimusaiheita rajataan, hypoteeseja asetetaan. Moni tutkija kuitenkin varoo antautumasta toimittajan juttusille, koska ei halua tulla kohdelluksi roolihenkilönä. Täl-

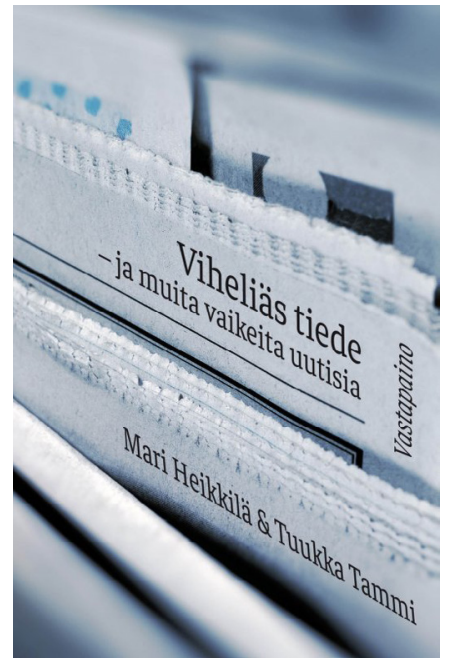

laisia pulmallisia tilanteita voisi liennyttää se, että tutkijat ja toimittajat etisivät yhdessä parempia tapoja viestiä tutkimuksesta laajemmalle yleisölle sen sijaan, että he syyttelevät toisiaan? Valaisevan esimerkin tarjoaa Mikko Hautakankaan, Pia Vuolannon ja Matleena Ylikosken keskustelu vaihtoehtohoitoihin liittyvästä viestintävyyhdestä.

Uskomukset ovat vahvimmillaan vihapuheeksi nimetyssä keskustelukulttuurissa, joka Minna Ruckensteinin käsittelyssä paljastuu enemmän yksinpuheluksi kuin minkään lajin keskusteluksi. Hän toteaa, että "vihapuhe on toiston taidetta". Siinä ei käydä dialogia vaan toistetaan toistamistaan jotakin vihamielistä väitettä jotain ihmisryhmää vastaan. Hän myös tarjoaa keinon murtautua mantrojen hokemisesta ulos: kaikenlainen puhe tulisi asettaa laajempiin yhteyksiin mediaympäristössä ja yhteiskunnassa. Neuvo sisältyy myös monen muun kirjoittajan 


\section{USKOMUKSET OVAT VAHVIMMILLAAN VIHAPUHEEKSI \\ NIMETYSSÄ KESKUSTELUKULTTUURISSA.}

tekstiin. Se on hyvä, ja sitä soisin sekä tutkijoiden että toimittajien noudattavan.

Tutkija joutuu toisinaan aiheidensa ja tulostensa herättämien myrskyjen riepoteltavaksi. Mikko Salasuo toteaa, että media havahtuu ja julkinen myrsky nousee helposti silloin, kun tieteellisesti koetellut tutkimustulokset ovat vakiintuneiden uskomusten vastaisia. Erityisen herkästi näin käy, jos tutkimustulokset haastavat jonkin yhteiskunnassa tärkeänä pidetyn elämänalueen uskomuksia. Tällaisia ovat Suomessa esimerkiksi urheilu tai maanpuolustus.

Karua kertomaa ovat myös Mari Heikkilän esimerkit siitä, kuinka vahvasti muut kuin tutkimuksesta nousevat intressit toisinaan vaikuttavat median uutisointiin. Yritykset ja myös aatteelliset järjestöt osaavat taivutella mediaa nostamaan esiin itselleen suotuisia tuloksia. Usein ne myös mainostavat itse tekemiään tai ulkopuolelta ostamiaan selvityksiä tutkimuksina ja paketoivat ne uutismuotoiseksi tiedotteeksi tai vähättelevät itselle epäsuotuisia tutkimustuloksia. Tupakkateollisuus on sinnikkäästi ja menestyksekkäästi käyttänyt kaikkia näitä keinoja omien etujensa ajamiseen. Heikkilä onkin oppinut kysymään tutkimuksen tekemisen motiiveja ja kyseenalaistamaan tutkimuksen luotettavuutta.

\section{KIIHKOA}

Toiseen alalukuun on valikoitu terveysaiheisia tekstejä: rokotekriittisyydestä, masennuslääkkeistä, sosiaalisen median äitiyskeskusteluista ja lasten mediankäytöstä. Kaikki ovat kieltämättä aiheita, jotka nostavat verenpainetta jo pelkkinä mainintoina.

Terveystoimittaja Ulla Järvi käsittelee tietoisen rauhallisesti aihettaan, rokotekriittisyyttä ja vaihtoehtohoitoja. Vaihtoehtohoidot esitetään usein hyvää tarkoittavien ihmisten toimintana, mutta taustalla on lääketeollisuuteen verrattavissa oleva miljardibisnes. Järvi kuitenkin muistuttaa, että läk̈ketieteessä on myös paljon hoitoja, jotka perustuvat tieteellisen näytön sijasta enemmän vakiintuneeseen kokemukseen. Kuinka erottaa medikalisaatiokriitikko puoskarista? Yksi keino on avoimuuden mittari: jos kriitikko ei suostu avoimeen dialogiin ja alkaa nähdä omien käsitystensä kanssa poikkeavien näkemysten edustajat salaliittolaisina ja vihollisina, hälytyskellojen tulee soida.

Teoksen toinen tekstimuotoinen dialogi käydään Jussi Valtosen ja Hannele Peltosen kesken. He keskustelevat psyykenlääkkeistä yhden Valtosen artikkelin aiheuttaman kiivailun pohjalta. Valtonen oli mainitussa tekstissään kysynyt, miksi masennuksen syynä pidetään yhä aivojen kemiallista epätasapainoa, vaikka kunnollista tieteellistä näyttöä siitä ei ole. Kysymys ja sen aiheuttama polemiikki osoittavat, että myös tieteellisen tutkimuksen kentillä kärjekkyydet nousevat usein ei-tieteellisistä motiiveista.

Raili Leino sohaisee ampiaispesää: somea ja sen äitiyskeskusteluja. Someaika tarjoaa loputtomasti tietoa, ja kaikki äitiyteen liittyvät ratkaisut ovat oikeita paitsi silloin, kun ne ovat vääriä. Leinon hauskanasiallisen tekstin viesti on, että kaikenlaisten muotivirtausten keskellä tärkeämpää kuin mikään muu on pitää järki päässä ja jalat maassa.

Toisinaan tutkija yllättyy huomatessaan, että hänen tuloksiaan ja jopa suoria haastattelusitaattejaan käytetään toimittajan ennalta valitseman draaman kaaren osina. Pahimmillaan tutkijasta tulee tahtomattaan roolihahmo kiihkeään debattiin, huokaisee Annikka Suoninen omassa kirjoituksessaan.

Anja Nysten kertoo yrityksestään oikaista Facebookissa levinnyttä erheellistä tietoa fluorin haitoista. Nopeasti hän oli saanut huomata, että virheellistä tietoa esittävien väitteiden kyseenalaistaminen on vähintäänkin vaikeaa. Kurmotuksen kohteeksi joutuu helposti kyseenalaistaja, ei suinkaan harhaanjohtavan materiaalin jakaja. Tarkoitushakuisten trollien kanssa ei kannata lähteä väittelyyn, mutta trollien motiivit kannattaa kaivaa esiin, neuvoo Nysten. 


\section{HELSINKIL ÄIST $\ddot{A}$ ÄSSÄ̈̈ ELI PISSISÄSS $\ddot{A}$}

\section{EI OLE KOSKAAN OLLUTKAAN.}

\section{VAUHTIA}

Arvelen, että ympäristöaiheet ovat olleet viheliäisten kysymysten kärkikymmenikön joukossa viimeistään siitä lähtien, kun antroposentrinen maailmankäsitys on alkanut vallita. Näistä teemoista teoksessa käsitellään biotaloutta, susikeskusteluja, rikkakasvien torjunnassa käytettyjä glyfosaatteja, Itämeren suolapulsseja ja muovien kulkeutumista ravintoketjuissa.

Miten toimia metsien kanssa? Kysymys herättää intohimoja: pitäisikö metsistä pitää huolta niiden biotaloudellisen arvon takia, vai olisiko ilmastotavoitteet asetettava ensisijalle? Mikko Pelttari purkaa auki metsäkeskustelun näkökulmia ja koettaa ymmärtää niitä hiukan syvemmin ja sitä kautta löytää ulospääsyä vallitsevasta riitelystä. Hän antaa tilaa aiheetta tutkineille tutkijoille suorien sitaattien muodossa, mikä kiittäen mainitaan.

Yksi takuuvarma vauhdikkaiden keskustelujen aihe on villipedot ja ihmisten suhtautuminen niihin. Marjatta Sihvonen piirtää ankaran kuvan siitä, millaiseen myllytykseen asiantuntija voi joutua, jos esittää julkisesti myönteisiä tai edes neutraaleja arvioita jostain yleensä kauhistuttavana esitetyn asian puolesta. Esimerkkitapaus kiinnittyy susiin.

Tieteellisten tulosten epävarmuus heijastudu muuhun yhteis- kuntaan muun muassa niin, että tieteen tuottamaan tietoon nojautuvien poliittisten päätösten teko saattaa viedä vuosia. Päivi Kaipiainen-Heiskanen nostaa tämän pulman esiin esimerkissään glyfosaattien käytön ohjeistamisesta viranomaistasolla.

Kirjan suloisin kätketty helmi on Kai Mybergin kirjoitus siitä, miksi Itämeren suolapulssit ovat sekä hyvä että huono asia. Hänen sanailussaan tiivistyy elegantisti koko teoksen metataso: vaivattoman tuntuisen tekstin myötä, ohimennen, lukija havahtuu huomaamaan, kuinka tärkeää sekä tiedejuttuja tehdessä ja lukiessa että itse tutkimuksen maailmoissa on pitää kirkkaasti esillä, mistä tarkkaan ottaen milloinkin on kyse.

Samaa teemaa hieman toiselta kannalta valottaa Eeva Pitkänen kertomuksessaan yhden juttunsa taustatyöstä. Tutkimustulos, jossa kerrottiin nanokokoisten muovipartikkelien päätyneen kalojen aivoihin ja muuttaneen niiden käyttäytymistä, uutisoitiin Suomessakin näyttävästi. Pitkäsen esiin kaivamassa tutkimusraportissa oli kyllä kerrottu myös, että tutkittu muovi oli varta vasten valmistettu menemään soluihin. Pitkänen pohtii, oliko pelottavan uutisen takana tutkimusryhmän tietoinen harhaanjohtava raportointi. Vai löytyykö syypää tutkimusraporttiin huolimattomasti perehtyneistä uutisoijista?

\section{VÄÄRINYMMÄRRYKSIÄ}

Viimeisen alaluvun sanailuissa käsitellään ja puretaan stereotypioita. Teemoina ovat muslimitaustaisten ihmisten luokittelu, musiikkikeskustelun kapeus ja seksi.

Helena Oikarinen-Jabai kertoo muutaman vuoden kestäneestä tutkimushankkeesta nuorten muslimitaustaisten nuorten kanssa. Viimeistään tuon ajan kuluessa hän sanoo havahtuneensa siihen, että uskontokunnat eivät ole monoliitteja, vaan ne elävät ja muuntuvat.

Teoksen kirjoittajista minut pääsi yllättämään Johanna Vaattovaara paljastamalla, että lingvistisenä entiteettinä helsinkiläistä ässää eli pissisässää ei ole koskaan ollutkaan. Suomalaiset ovat 1800-luvulta lähtien olettaneet, että pääkaupunkilaisilla on erilainen 's' kuin muilla suomalaisilla. Aihetta on tutkittu kuitenkin vasta 2000-luvulla, ja tutkimukset osoittavat olettaman erheelliseksi. Sosiaalisena entiteettinä helsinkiläinen 's' sen sijaan elää ja voi hyvin, mikä kertoo enemmän kielenulkoisesta todellisuudesta kuin kielestä itsestään.

Reippaana sanailijana tunnettu Antti-Ville Kärjä posauttaa pirstoiksi yleisen käsityksen, jonka mukaan musiikki kuuluu vain harvoille ja valituille. Hän toteaa, että musiikki kuuluu kaikille ja että musiikista tulee "oikeaa" tai "vää- 
rää" vasta, kun se kytkeytyy valtaja arvoasetelmiin. Voi olla, että ihminen ei ole perehtynyt musiikin teoriaan tai nuotitukseen, mutta se ei tarkoita, etteikö tämä ymmärtäisi musiikista yhtään mitään.

Kirjan päättää Salla Nazarenkon ja Matti Huttusen keskustelu uskottomuudesta, parisuhteesta, rakkauden ja seksuaalisuuden muodostamasta vyyhdistä sekä siitä, puhutaanko seksistä liikaa. Parisuhde ja seksuaalisuus sen osana on erittäin hyvä esimerkki yksityisen ja yleisen elämänpiirin toisissaan olemisesta: parisuhde on myös yhteiskunnallinen ilmiö, ja uskottomuus rikkoo sekä yksikön että yhteisön turvallisuudentunnetta. Tarve vastavuoroisiin ihmissuhteisiin ja kuuluvuuteen on elämän kannalta seksuaalista viettiä tärkeämpi tarve, ja Huttunen arvelee, että tämä tekee uskottomuudesta ongelman.

\section{NIUHOTTAMISTA JA KEHUJA}

Pari sanaa typografiasta. Tekstin luettavuuteen vaikuttaa yllättävän paljon se, miten teksti on teoksen sivulle juoksutettu. Palsta on tässä kirjassa lukuystävällinen, rivivälit ja sanavälit toimivat, perusasiat ovat kunnossa. Mutta joskus vähemmän on enemmän - niin nätiltä kuin keskelle tasattu kursivoitu teksti näyttääkin, sitä on hankala lukea edes muutamaa rivin mittaa. Lisäksi paikoin hupsut tavutukset kertovat kiireestä kirjan viimeistelyvaiheessa. Kyllä me lukijat olisimme malttaneet vielä muutaman päivän odottaa, että taittaja olisi saanut viimeistellä oman työnsä kauniisti ja rauhassa.
Kirjan tekstien ryhmittely valittuihin alalukuihin toimii, mutta loppuviimein mikä tahansa teksti sopisi minkä tahansa alaotsikon alle. Alaluvut kyllä muodostavat kokonaisuuksia, mutta itse luin kirjan selaillen sieltä täältä, mihin lukutapaan teos taipuu hyvin lyhyiden ja intensiivisten tekstiensä ansiosta. Novellikokoelma tämä ei kuitenkaan ole, olisiko esseekokoelmakaan. Ehkä voisi puhua tietolastuista.

Teoksen kirjoittajat ovat kokeneita ja kannuksensa ansainneita tiedetoimittajia ja -viestijöitä. Tuon takia toimitustyö lie ollut tavallisuudesta poikkeavaa, kaikilla kun on varmasti ollut perusteltuja mielipiteitä oman ja vähän muidenkin tekstien sanomisen tavoista. Ammattilaisina tämä joukko on varmasti myös ollut keskimääräistä suostuvaisempaa muokkaamaan tekstejään. Yhtä kaikki, joukkoa paimentaneet teoksen toimittajat Tuukka Tammi ja Mari Heikkilä ovat pitäneet laumansa ruodussa ja tehneet oman osuutensa erittäin hyvin.

Kirjalle erityistä prestiisiä tuovat erityisesti kolme kirjoittajaa: Ulla Järvi, Raili Leino ja Matti Huttunen. Legendaariset tiedetoimittajat Järvi ja Leino ovat aina esimerkillisesti asiassa ja asiallisia, ja Huttunen on osallistunut aktiivisesti ja ansiokkaasti omasta alastaan, psykiatriasta, käytyihin keskusteluihin myös ammattipiiriensä ulkopuolella.

Kirja herättelee lukijansa jo yksin lastuissa käsiteltyjen aiheiden ansiosta, ja tekstien omakohtaisuus tuo abstraktit episteemiset kysymykset liki myös lukijaa usea teokseen kirjoittanut on tiedetoimittajuutensa lisäksi tutkija. Mutta hyvästi kirjoitetuista teksteistä huolimatta oloni oli ensimmäisiä lastuja lukiessa kuin olisin pukenut alushameen juhlamekon alle väärin päin.

Kiemurteluni loppui, kun tajusin, mikä niin vaivasi. Viheliäästä tieteestä puuttuu viiteapparaatti lähes kokonaan, muutama alaviite sentään on. Ensimmäistäkään oikeaa lähdeluetteloa sen sijaan kirjasta ei löydy. Erityisesti humanistisiin ja yhteiskuntatieteellisiin teksteihin tottuneena tällainen tapaisuus on minulle vieras.

Mutta niin, tätä tiedetoimittajien kokoomateosta ei ole tarkoitettukaan tiedekirjaksi, se on tietokirja tiedeviestinnästä, kelpo sellainen. Ensinnäkin kuka tahansa lukija yleissivistyy. Toiseksi teos toimii ainakin 1) vertaistukena tiedetoimittajakollegoille, 2) muistilistana tutkijoille, mihin kannattaa kiinnittää huomiota silloin, kun on median kanssa tekemisissä ja 3) johdattelevana oppikirjana niille, jotka pohtivat, josko uskaltautuisivat kokeilemaan siipiään tiedeviestinnän ja -toimittamisen aloilla.

Ja niinpä vain on upeasti toimitettuun kirjaan jäänyt ainakin kolme typoa. Toimittajat ja teoksen kustannustoimittaja ovat ehkä jättäneet ne sinne tahallaan, antamaan lukijoilleen mahdollisuuden armeliaaseen suopeuteen: eivät nämäkään ihan täydellisiä ole.

\section{RIITTA KOIKKALAINEN}

YTM, tietoasiantuntija,

tiedetoimittaja

Kansalliskirjasto 